\title{
The Comparison of Self-Efficacy Dimensions in ADHD and Normal Students
}

\author{
Nosrat Ghafarzade Almasi \\ Department of Psychology, Kish International Branch, Islamic Azad University, Kish Island, Iran \\ Email: almasi9599@yahoo.com
}

How to cite this paper: Almasi, N.G. (2016) The Comparison of Self-Efficacy Dimensions in ADHD and Normal Students. Open Journal of Medical Psychology, 5, 88-91.

http://dx.doi.org/10.4236/ojmp.2016.54010

Received: September 12, 2016

Accepted: October 28, 2016

Published: October 31, 2016

Copyright $\odot 2016$ by author and Scientific Research Publishing Inc. This work is licensed under the Creative Commons Attribution International License (CC BY 4.0).

http://creativecommons.org/licenses/by/4.0/

\begin{abstract}
The study aimed to compare the efficacy of ADHD and normal students. This study is a comparative study and a case-control. The population consisted of all male students in second and third high-school in the school year 2015 in Delijan city. The sample consisted of 60 boys with ADHD who were selected from 1200 students through clinical interviews. Moreover, 60 normal students who were selected by matching method. Results of data were analyzed using multivariate analysis of variance. The results of multivariate analysis of variance showed a significant difference between the two groups of students in terms of efficacy $(P>0.01)$.
\end{abstract}

\section{Keywords}

Self-Efficacy, ADHD, Students

\section{Introduction}

Studies have shown that the prevalence of ADHD in children is 4 to 10 percent of the population, which is common [1] [2] [3]. And it is not just restricted to childhood but 50 to 80 percent of cases are in young adults [4]. Reports show that at least 35 percent of adolescents with ADHD have once been expelled from school and the percentage of normal adolescents is 8 to 10 percent [5]. There is evidence that higher levels of selfefficacy in students increase academic motivation [6]. In fact, such variables are likely to be low levels of self-efficacy in adolescents with ADHD. Self-understanding is a possibility of commitment to a work program and increases health-promoting behaviors [7]. [8] in separate studies has shown that ADHD will have a negative impact on the success of social, educational and emotional development [8] [9]. This research is important. The aim of this study was to compare the efficacy of students with attention deficit/hyperactivity disorder and normal students [10] [11]. 


\section{Material and Methods}

This research is a comparative study and case-control. The population consisted of all male students in second and third high school in school year 2011-2012 in Delijan city. The sample consisted of 60 boys with ADHD who were selected from among 1,200 students through clinical interviews. In addition, 60 normal students in a way that matched (based on education, father, maternal education and birth) were selected. The following tools were used to collect data: 1

- Scale of Attention Deficit/Hyperactivity Adults: The scale has 26 items. The raw scores of the scale using proper norm table are converted to T scores. T-scores above 65 are clinically meaningful and $\mathrm{T}$ scores above 80 in addition to the pathology of the problem and the field shows they also raised the possibility of exaggeration of symptoms. Its reliability and validity of the questionnaire manufacturers vary from 850 to 0.95 to 0.37 from 0.37 reported (Conner et al., 1999). Internal consistency reliability of the scale, the Cronbach's alpha coefficient $(r=0.81)$ and its content validity was confirmed through three specialty children.

- Self-Efficacy Scale: Scale is self-adolescents 24 article by Morris (2001) has been made. Subjects with a five-point scale (very bad to very good) response, this self-efficacy questionnaire with three subscales academic, social and emotional measures and alpha has been reported that 0.88 . The correlation coefficient between this questionnaire and children's questionnaire $(0.40)$ is obtained $(0.01<\mathrm{P})$. Finally, after the study, collected data using multivariate analysis of variance were analyzed.

\section{Results}

Before using multivariate analysis of variance to comply assumptions of parametric tests, the test box and cauliflower were used. Based on the test box was not significant for any of the variables, the condition of homogeneity of variance matrices/covariance is properly observed $(\mathrm{P}=0.82, \mathrm{~F}-0.63, \mathrm{BOX}=8.13)$ (Table 1$)$. According to Levene test and non-significant for all variables, the condition of equality between group variances was not met. Wilks Lambda test results showed that the combined effect of group selfefficacy component of academic, social and emotional is significant $(0.001>\mathrm{P}, \mathrm{F}=3.26$, Wilks Lambda $=0.106)$. The results showed that at least one of the studied variables there are significant differences between the two study groups.

Multivariate analysis showed that the mean scores for self-education $(\mathrm{F}=112.99)$, social self-efficacy $(F=699.13)$ and emotional self-efficacy $(F=510.67)$ was significantly higher in normal school students ADHD $(\mathrm{P}>0.001)$ (Table 2).

\section{Discussion}

This study compared the efficacy of students with attention deficit/hyperactivity disorder and normal students. These findings are consistent with other research findings (for example, Pajars, 2000; Parry et al., 2002; Foreign et al., 2003; Johnson et al., 2008). Efficacy as an institution, is exercising control over the individual [12]. However, various studies have shown that teens with ADHD are facing academic difficulties [5]. 
Table 1. Mean and standard deviation of self-efficacy in ADHD and normal students.

\begin{tabular}{cccccc}
\hline \multicolumn{2}{c}{ Normal Students } & \multicolumn{2}{c}{ ADHD students } & & \multicolumn{2}{c}{ Index } \\
\hline $\begin{array}{l}\text { Standard } \\
\text { deviation }\end{array}$ & Average & Standard deviation & Average & & \\
\hline 3.27 & 24.95 & 4.09 & 17.75 & Educational & Self-Efficacy \\
2.14 & 29.28 & 3.05 & 16.53 & Social & \\
2.13 & 27.75 & 3.61 & 15.50 & Emotional & \\
\hline
\end{tabular}

Table 2. Results of multivariate analysis of variance on average dimensions of self-efficacy in students with ADHD and normal students.

\begin{tabular}{cccccc}
\hline Significance level & F & Mean Square & $\begin{array}{c}\text { Degrees of } \\
\text { freedom }\end{array}$ & Sum of squares & The dependent variable \\
\hline 0.001 & 112.99 & 1555.20 & 1 & 1555.20 & Academic Self-Efficacy \\
0.001 & 699.13 & 4876.87 & 1 & 4876.87 & Social Self-Efficacy \\
0.001 & 510.67 & 4501.87 & 1 & 4501.87 & Emotional Self-Efficacy \\
\hline
\end{tabular}

In terms of individuals and peers, teens with ADHD are more domineering and annoying; in fact, these young people ensure homogeneous react with intolerance and avoidance [13]. Rejection in class leads to social isolation, rejection by peers and ultimately to reduce the social efficacy. Finally we can say that emotional self-perception of their ability can control and manage feelings and negative thoughts [14]. They cannot get their excitement for the benefit of adjusting for other thrill and excitement, and this is what is called self-control. In general, these teenagers are lacking in emotional selfcontrol and self-efficacy.

\section{References}

[1] Teeter, P.A. (1998) Interventions for ADHD: Treatment in Developmental Context. Guilford Press, New York, 276-319.

[2] Alizadeh, H. (2004) Attention Deficit-Hyperactivity Disorder. Roshd. Publishing House, Tehran.

[3] Skounti, M., Philalithis, A. and Galanakis, E. (2007) Variations in Prevalence of ADHD Worldwide. European Journal of Pediatrics, 166, 117-123. http://dx.doi.org/10.1007/s00431-006-0299-5

[4] Barkley, R.A. (2003) Issues in the Diagnosis of Attention-Deficit Hyperactivity Disorder in Children. Journal of Brain and Development, 25, 77-83. http://dx.doi.org/10.1016/S0387-7604(02)00152-3

[5] Goldstein, S. and Goldstein, M. (1998) Managing Attention Deficit Hyperactivity Disorder in Children: A Guide for Practitioner. 2nd Edition, Wiley, NY.

[6] Caprara, G.V., Giunta, L.D., Eisenberg, N., Gerbino, M., Pastorelli, C. and Tramontano, C. (2008) Assessing Regulatory Emotional Self-Efficacy in Three Countries. Psychological Assessment, 20, 227-237.

[7] Pender, N.J., Murdaugh, C. and Parsons, M.A. (2002) Health Promotion in Nursing Prac- 
tice. 4th Edition, Prentice-Hall Health, Inc., USA, 140-145.

[8] Pary, R., Lewis, S., Matuschka, P.R., Rudzinskiy, P., Safi, M. and Lippmann, S. (2002) Attention Deficit Disorder in Adults. Annals Clinical Psychiatry, 14, 105-111.

http://dx.doi.org/10.3109/10401230209149097

[9] Faigel, H.C. (1995) Attention Deficit Disorder in College Students: Facts, Fallacies, and Treatment. Journal of American College Health, 43, 147-55.

http://dx.doi.org/10.1080/07448481.1995.9940467

[10] Wolters, C.A. (1999) The Relationship between High School Students' Motivational Regulation and Their Use of Learning Strategies, Effort, and Classroom Performance. Learning and Individual Differences, 11, 281-301.

[11] Johnston, C., Hommerson, P., \& Seipp, C. (2008) Acceptability of Behavioral and Pharmacological Treatment for Attention-Deficit/Hyperactivity Disorder: Relations to Child and Parent Characteristics. Behavior Therapy, 39, 22-32.

http://dx.doi.org/10.1016/j.beth.2007.04.002

[12] Bandura, A. (1997) Self-Efficacy: The Exercise of Control. H. W. Freeman and Company, New York.

[13] Hajlin, R.P. and Vitborn, S.C. (2003) Psychopathology: Clinical Perspectives on Mental Disorders According to DSM-IV-TR (Volume II). Translated in Persian by Yahya Seyed Mohammadi, Mental, Tehran.

[14] Scheres, A., Osdterlan, J., Geurts, H., Morein-Zamir, S., Meiran, N., Schut, H., Vlasveld, L. and Sergeant, J. A. (2004) Executive Functioning in Boy with ADHD: Primarily an Inhibition Deficit? Archives of Clinical Neuropsychology, 19, 569-594.

http://dx.doi.org/10.1016/j.acn.2003.08.005

Submit or recommend next manuscript to SCIRP and we will provide best service for you:

Accepting pre-submission inquiries through Email, Facebook, LinkedIn, Twitter, etc. A wide selection of journals (inclusive of 9 subjects, more than 200 journals)

Providing 24-hour high-quality service

User-friendly online submission system

Fair and swift peer-review system

Efficient typesetting and proofreading procedure

Display of the result of downloads and visits, as well as the number of cited articles

Maximum dissemination of your research work

Submit your manuscript at: http://papersubmission.scirp.org/

Or contact ojmp@scirp.org 